\title{
CONTRIBUIÇÕES DE MICHEL FOUCAULT AO ESTUDO DA FILOSOFIA ANTIGA: 0 CONCEITO DE PARREHSÍA APLICADO AO FEDRO DE PLATÃO
}

\author{
MICHEL FOUCAULT'S CONTRIBUTIONS TO THE STUDY OF ANCIENT PHILOSOPHY: THE \\ CONCEPT OF PARREHSÍA APPLIED TO THE PHAEDRUS OF PLATO
}

Gabriel Rodrigues Rocha*

\section{RESUMO}

O artigo analisa a interpretação foucaultiana do diálogo intermédio Fedro, de Platão. Neste propósito, para Michel Foucault, a querela entre retórica e filosofia, e entre a oralidade e a escrita, é de menor importância em relação à questão da utilização boa ou má do logos. Do que se segue - no uso foucaultiano -, o uso apropriado do logos faz-se a partir de três prévios requisitos: a parrhesía, a psicagogia e a dialética. A filosofia de Platão, analisada a partir do referido diálogo Fedro, propõe um novo lugar (tópos) ao uso discursivo do logos. Em consequência, o logos filosófico constrói-se em direta relação com a verdade do enunciado e, em consequência, com a eticidade do discurso. Assim apresenta-se como definitivo a ruptura com o que se denominou de uso procedimental da retórica. Isto é, a sua utilização puramente formal e instrumental ao processo persuasivo. A propósito, viés este largamente utilizado na tradição sofistica, à qual a tradição socrático-platônica irá veementemente se opor.

PALAVRAS-CHAVE: Filosofia. Parrhesía. Platão. Psicagogia. Retórica.

\section{ABSTRACT}

The article analyzes Foucault's interpretation of the intermediate dialogue Phaedrus, Plato. In this way, to Michel Foucault, the quarrel between rhetoric and philosophy and between orality and writing, are of minor importance in relation to the question of good or bad use of logos. following the - in Foucault's use - that the proper use of logos is made from three prerequisites: parrhesia, the psicagogia and dialectics. Plato's philosophy, analyzed from said Phaedrus dialogue, proposes a new place (topos) the discursive use of logos. Consequently, the philosophical logos builds up in direct relation to the truth of the statement and, as a result, with the ethics of discourse. Thus it is presented as definitive the break with what is termed procedural rhetoric use. That is, its use purely formal and instrumental to the

\footnotetext{
* Doutor em Filosofia. Tese e pesquisas primordialmente desenvolvidas na área de ética e filosofia antiga. Graduado em Filosofia e História. E-mail: gabiphilo78@ gmail.com.
} 
persuasive process. By the way, this bias widely used in sophisticated tradition, to which the Socratic-Platonic tradition will vehemently oppose.

KEY-WORDS: Philosophy. Parrhesía. Plato. Psicagogia. Rhetoric.

\section{INTRODUÇÃO}

Autor de extensa produção, em diferentes âmbitos de interesse, Michel Foucault produz e desenvolve uma significativa contribuição aos estudos de filosofia antiga. De Platão ao estoicismo imperial romano, Foucault enriquece e inova em análises interpretativas ao debruçar-se aos estudos clássicos. Mediante a própria extensão de sua grade interpretativa, não se torna possível abranger toda a gama temática da filosofia antiga, tal como aparece nas obras de Foucault, a saber, fundamentalmente, nas obras Hermenêutica do sujeito, História da sexualidade e $O$ governo de si e dos outros. Assim, escolhe-se um conceito específico implicado diretamente na tradição platônica: o conceito de parrhesía. Todavia, ainda sobre o conceito escolhido à presente análise, também a este, por motivos de delimitação e objetividade textual, reduz-se a proposta interpretativa ao estudo que Foucault apresenta sobre o conceito de parrhesía, em sua apropriada relação com o diálogo platônico Fedro ${ }^{1}$.

\section{0 diálogo Fedro e o uso apropriado do logos}

O núcleo de análise desta proposta temática repousa na parte final do diálogo platônico Fedro, a saber, a parte diretamente endereçada ao estudo sobre a retórica. Como argumenta Foucault (2010, p. 297): "Em certo sentido o problema filosofia/retórica perpassa toda a obra de Platão."

Em diálogo homônimo, o personagem Fedro define com exatidão a impropriedade na utilização do logos pela sofística e pelos retóricos, porquanto há uma desconexão entre o que é e o que aparenta ser. O discurso assume formas pretensamente verdadeiras de saber, mas que não passam de simples opiniões (doxai); no entanto, para o público em geral, o seu proferidor assume o caráter de grande sabedor.

A utilização apropriada do logos não dispensa a parrhesía, ao contrário, faz desta condição de enunciação do discurso verdadeiro. Conforme propõe Foucault (2010, p. 43): “A

\footnotetext{
${ }^{1}$ Este estudo consta da "Aula de 02 de março de 1983 - segunda hora". As citações deste texto referem-se à edição aqui utilizada (FOUCAULT, 2010).
} 
Artigo: Contribuições de Michel Foucault ao estudo da filosofia antiga: o conceito de parrehsía aplicado ao Fedro de Platão

parrhesía é o encontro com o outro pela mediação da palavra, da palavra que fala a verdade de si para a verdade do outro. Portanto, a parrhesía vincula-se ao uso apropriado do $\operatorname{logos}^{2}$." Do que se segue que jamais é permitido desvincular a condição de verdade do discurso do discurso em si mesmo. Contudo, pondera Foucault (2010, p. 300) que "a relação de discurso e verdade não deve ser posta antes do próprio discurso, mas ser algo constante e permanente no próprio discurso". O discurso é, portanto, uma relação construtiva de verdade realizado no raciocínio e no método dialético, em exposição preferencialmente dialógica ${ }^{3}$.

A forma dialogal que serve de instrumento para a exposição dos princípios da filosofia de Platão, possui, em excelência, a característica parresiástica no uso da palavra. É nesta linguagem dialógica e dialética que se criam condições para evitar o erro, as falsas opiniões e os falsos enunciados, havendo assim uma verdadeira condução (psicagogia) do pensamento (diánoia), através do discurso, para o mais verdadeiro.

É válido afirmar que tais problemáticas são originariamente filosóficas, e não parece haver nenhuma preocupação, da parte de sofistas e retóricos, com tais questões. Há assim evidente ruptura entre o discurso filosófico e o discurso retórico, pois, como é demonstrado na parte final do diálogo Fedro, Sócrates justifica o porquê de a retórica não ser a arte (tekhne) do discurso do logos.

Esse ponto é significativo, pois Sócrates, em seus argumentos, está apresentando uma crítica fundamental à retórica enquanto técnica essencialmente procedimental, isto é, a sua tradicional utilização. Mas tal crítica não abrange a retórica enquanto tal, porquanto, dada a esta a devida orientação, é possível utilizá-la sem a desvincular das excepcionais condições necessárias ao uso apropriado do logos, no manuseio com a utilização da palavra e da razão discursiva. Torna-se assim imprescindível associar a retórica com o discurso eminentemente filosófico.

Nesse propósito eleva-se a retórica a outro patamar. Seu status não deve ser o do convencimento a qualquer custo, mas a eticidade da palavra deve vincular-se, necessariamente, aos procedimentos de persuasão. Esse aspecto ético do uso do logos também encerra em si a sua função política, isto é, a função pública do uso do discurso em sua melhor contribuição à vida da pólis.

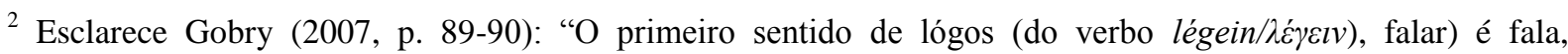
linguagem. Ora, a linguagem é a expressão do pensamento. [...] De fato, a palavra logos tem um sentido muito matizado, que pode ser dividido em três: Faculdade mental superior, sinônimo de inteligência conceitual e raciocinante; raciocínio; conceito."

${ }^{3}$ Para Gobry (2007, p. 40): “A dialética é, em seu primeiro sentido, um diálogo. Platão, que adota esse termo em filosofia, lhe dá o sentido de ascensão espiritual. "
} 
Como em Platão, a harmonia do Estado é uma correspondência à harmonia da alma (psyché), somente a racionalidade discursiva de um logos ético e correlato à verdade poderá servir de fundamento aos ideais filosóficos e políticos do platonismo.

É em relação a esse âmbito do político que se inscreve a tese do rei-filósofo exposta no diálogo República. Por ser capaz de aplicar o governo de si próprio ao que lhe é inferior, ao que se lhe constitui de natureza inferior na alma concupiscente (epithymía), o filósofo propõese exitosamente ao governo dos outros. É nesse sentido que o saber filosófico se torna indispensável ao saber político, ao saber daquele que governa ${ }^{4}$.

Como exemplarmente consta na Carta VII (326 b):

Fui obrigado a dizer, louvando a verdadeira filosofia, que a ela cabe discernir o politicamente justo em tudo dos indivíduos, e que a espécie dos homens não renunciará aos males antes que a espécie dos que filosofam correta e verdadeiramente chegue ao poder político, ou a espécie dos que têm soberania nas cidades, por alguma graça divina, filosofe realmente.

Nota-se a excepcional importância da parrhesía, excepcionalidade percebida por Foucault, na compreensão do discurso verdadeiro que forma e prepara o governo, o espaço público e a vida ética. Portanto, trata-se também, infere-se, de uma apologia à filosofia contra seus adversários.

A retórica enquanto somente procedimento persuasivo que objetiva demonstrar o que ora pode ser tido como justo, mas, que por força de circunstâncias poderá ser categorizado também como injusto, não pode jamais satisfazer às pretensões de verdade e eticidade do discurso filosófico. Assumir hipotética possibilidade seria aderir ao relativismo protagoriano, jamais aceito e, ao contrário, fortemente combatido pelos postulados filosóficos de Platão.

É importante sempre considerar a oposição, em absoluto, por parte de Platão em relação à tese protagoriana de tomar "o homem como medida de todas as coisas". Não pode haver relativismo acerca de princípios como o Bem ou o Justo. E muito menos aceitar uma certa espécie de subjetivismo, acerca do que se constitui, como fundamento, do real verdadeiro. Por conseguinte, é extremamente espantoso do ponto de vista filosófico que Fedro, no diálogo homônimo (260 a), sentencie a Sócrates “que teria ouvido dizer” que:

\footnotetext{
4 “Parrhesía [...] uma certa forma de discurso político que teria como objeto o governo do Príncipe, o governo da alma do Príncipe pelo conselheiro, pelo filósofo, pelo pedagogo, que é encarregado de formar sua alma. Discurso verdadeiro, discurso de verdade endereçado ao Príncipe e à alma do Príncipe” (FOUCAULT, 2010, p. 8).
} 
[...] para quem deseja tornar-se um orador consumado, não se torna necessário um conhecimento perfeito do que é realmente justo, mas sim do que parece justo aos olhos da maioria [...] Tão pouco precisa saber realmente o que é bom ou belo, bastando-lhe saber o que parece sê-lo, pois a persuasão se consegue não com a verdade, mas com o que aparenta ser verdade.

Proceder nesse sentido seria negar a função parresiástica do discurso, e separar o discurso filosófico de princípios universais, tão caros ao platonismo.

Do que se segue que o uso do logos no discurso filosófico não está de forma alguma submetido às circunstâncias de embate argumentativo, que comumente prescinde dos conceitos que expressem o valor de verdade. Assim, o que seja o justo ou o injusto, bom ou mau, moderado ou imoderado não deve sê-lo mediante o resultado comum de um simples acordo mútuo realizado a partir de uma persuasão não filosófica, isto é, de acordo com algo que parece ser conveniente a algum momento em específico em detrimento de uma ocupação, imagem ou exercício de poder. Por conseguinte, não deve ser algo tido como verdadeiro porque a maioria persuadida assim o classifica, mas por ser verdadeiro, deve, em sua consequência, ser passível de adesão. Este é o ponto exato em que a filosofia não prescinde da retórica, mas utiliza-se desta, ao mesmo tempo em que orienta e reclassifica o seu próprio uso procedimental.

Este é o sentido compreendido por Foucault (2010, p. 301), quando pondera "que Sócrates coloca a retórica no âmbito no qual a retórica se situa ou deveria se situar, que é a psicagogia (a condução das almas) pelos discursos".

Portanto, há clara cisão entre o discurso filosófico parresiasta e psicagógico, e a utilização procedimental do tradicionalismo retórico de políticos e oradores, como é possível depreender-se na seguinte passagem do diálogo Fedro (261 c-d):

Como procedem nos tribunais, os advogados das partes em litígio? Não procuram contradizer as afirmações um do outro? Ou não será assim? Contradizem-se, então sobre o que é justo como sobre o que é injusto? E não achas então que, fazendo isso com arte, se pode conseguir que a mesma coisa pareça aos homens ora justa, ora injusta, conforme as conveniências [...] E quando se trata das arengas políticas não achas que acontece o mesmo, que a mesma coisa parece aos cidadãos, ora justa ora injusta?

Mediante a análise da utilização platônica do logos, deve-se ponderar sobre a questão do logos escrito. Conforme assere Foucault (2010, p. 299-300), em sua interpretação da quarta parte do Fedro, existe uma oposição corrente ao tempo de Sócrates e Platão que é a questão 
entre o discurso escrito produzido pelos logógrafos e o uso do logos vivo do discurso oral ${ }^{5}$. Contudo a questão que essencialmente importa aos filósofos é o que diferencia o mau do bom discurso.

Adentra-se, assim, em um ponto de notável relevância tanto ao socratismo quanto ao platonismo: a questão da educação (paideía) da alma (psyché) ${ }^{6}$.

Evidencia-se assim a existência de um telos, para o qual se deve dirigir o discurso filosófico, e este telos é a educação da alma. É mediante este propósito final que se deve fundamentar com rigor a devida apropriação na utilização do logos. Daí infere-se que a questão do logos oral, ou escrito, esteja pormenorizada, porquanto encontra-se a significabilidade filosófica, na aplicação realizada no uso correto ou não que se apresenta do $\log$ os.

Desse modo, as questões se entrelaçam e participam umas das outras, efeito típico do platonismo. A paideía, a política e a parrhesía se imiscuem no discurso formativo de si, isto é, na formação/construção de uma psyché apta e capaz de exercer o que melhor lhe cabe, dentro de suas particularidades e tendências internas, objetivando assim a melhor construção possível da comunidade política.

O eminente platonista T. Szlezák (2005. p. 62), ao analisar o telos da comunicação filosófica em Platão, afirma que:

\footnotetext{
${ }^{5}$ Sobre a questão da escrita na Antiguidade ajuíza Hadot (2012, p. 28-29): "As obras escritas dessa época [Antiguidade] permanecem estreitamente ligadas a condutas orais. Elas frequentemente são ditadas a um escriba. E são destinadas a ser lidas em voz alta, seja por um escravo que fará para seu mestre, seja pelo próprio leitor, pois ler, na Antiguidade, é habitualmente ler em voz alta, sublinhando o ritmo do período e a sonoridade das palavras que o autor já pode ele mesmo experimentar quando ditava sua obra. Os antigos eram extremamente sensíveis a esses fenômenos sonoros. Poucos filósofos na época que estudamos resistiram a essa magia do verbo, nem mesmo os estóicos, nem mesmo Plotino. [...] Essa ligação da escrita com o discurso explica, pois, certos aspectos das obras da Antiguidade. Muito frequentemente, a obra se desenvolve por associações de ideias, sem rigor sistemático; ela deixa subsistir as retomadas, as hesitações, as repetições [...] acrescentando introduções ou conclusões às diferentes partes. Mais que todas as outras, as obras filosóficas estão ligadas à oralidade, porque a própria filosofia antiga é, antes de tudo, oral. Sem dúvida, pode ocorrer que alguém se converta lendo um livro, mas ele logo se lança junto ao filósofo para escutar seu discurso, interrogá-lo, discutir com ele e com outros discípulos, numa comunidade que é sempre um lugar de discussão. Com relação ao ensino filosófico, a escrita não é senão um pró-memória, um recurso que jamais substituirá o discurso vivo. A verdadeira formação é sempre oral, porque somente o discurso permite o diálogo, isto é, a possibilidade para o discípulo de ele próprio descobrir a verdade no jogo de questões e respostas e também a possibilidade para o mestre de adaptar seu ensino às necessidades do discípulo. Numerosos filósofos, e não dos menores, não quiseram escrever, considerando, como Platão e sem dúvida com razão, que o que se escreve nas almas pelo discurso é mais real e mais durável do que os caracteres traçados sobre o papiro ou o pergaminho. " É válida a ressalva que entre Foucault e Pierre Hadot houvera uma recíproca teórica, embora, quanto à análise da filosofia antiga haja pequenas divergências interpretativas.

${ }^{6}$ Assere Trabatonni (2010, p. 131-32): "Desde os tempos de Homero, a alma representava a vida do corpo. Todavia, Platão aceita a provável posição do Sócrates histórico, que abandona o aspecto fisiológico (alma como apenas o que mantém o corpo vivo) para uma imagem espiritual: a alma é, antes de tudo, a sede do intelecto e da consciência e é o sujeito das ações e dos valores morais".
} 


\begin{abstract}
A meta da comunicação do conhecimento é 'clareza e certeza' [...] Essa meta só pode ser alcançada por meio do logos vivo da oralidade, mas, como Platão entende o logos escrito como imagem (eídolon) do oral (Fedro, 276 a 8-9), a escrita também deve, em último termo, visar à mesma meta, ainda que jamais a possa alcançar.
\end{abstract}

A interpretação sugerida por Szlezák possibilita crer no uso intencional da forma dialógica como o modo propositadamente escolhido para a expressão do logos filosófico, sendo o local (tópos) de intersecção entre oralidade e escrita. No entanto, como demonstra Foucault, a questão fundamental é sempre a utilização do logos mais que a sua forma.

Sugere-se que o interesse de Foucault por Platão e a questão entre discurso filosófico e retórica advém do interesse foucaultiano na formação subjetiva dos sujeitos. Afinal, o discurso e a razão discursiva constituem-se como práticas de si, que fomentam a formação de subjetividades $^{7}$.

Nesse sentido Foucault caracteriza a filosofia antiga como modo fundador a partir de dois princípios: o "conhece-te a ti mesmo" (gnôthi seautón) e o "cuidado de si mesmo" (epimelô̂ heautoû) como sendo saberes basilares na relação entre subjetividade e verdade, bem como o conhecimento do sujeito por ele mesmo ${ }^{8}$.

Em suma, se o uso apropriado do logos vincula-se ao uso que a filosofia faz deste e, se o objetivo da filosofia de Platão direciona-se sempre a uma correta formação educativa da psyché, supõe-se evidente que o uso da linguagem discursiva produzida na filosofia caracteriza-se como profunda "técnica de si” indispensável à formação moral e política dos indivíduos. Disso se pode assumir o seguinte posicionamento da filosofia platônica: ela é extremamente vinculada a práxis, ou seja, tem sempre em vista a ação humana. É exatamente por isso que o filósofo, embora contemple o mais verdadeiro ou o realmente real após sair da Caverna, para esta deve retornar. Este é, portanto, o compromisso social e político da filosofia: o da condução (psicagogia) e educação (paideía) das almas. Donde o discurso em sua expressão parresiasta jamais pode ser prescindido.

\footnotetext{
7 “[...] Pareceu-me que seria preciso tentar analisar as diferentes formas pelas quais o indivíduo é levado a se constituir como sujeito [...] Em outras palavras [...] indo da questão do sujeito à análise das formas de subjetivação, e de analisar essas formas de subjetivação através das técnicas/tecnologias da relação consigo ou, vamos dizer, através do que pode chamar de pragmática de si” (FOUCAULT, 2010, p. 6).

8“Parece-me que a noção de epiméleia heautoû acompanhou, enquadrou, fundou a necessidade de conhecer-se a si mesmo não apenas no momento de seu surgimento no pensamento, na existência, no personagem de Sócrates. Parece-me que a epiméleia heautoû (o cuidado de si e a regra que lhe era associada) não cessou de constituir um princípio fundamental para caracterizar a atitude filosófica ao longo de quase toda a cultura grega, helenística e romana" (FOUCAULT, 2006 p. 11-12).
} 
Torna-se apreensível a compreensão do seguinte argumento do diálogo Górgias (504 d-e $)^{9}$, que assim como o Fedro, apresenta a questão da retórica e a relação com a filosofia:

É que o orador honesto e competente deverá dirigir seus discursos à alma dos homens, sempre que lhes falar, e todos os seus atos [...] deverá pensar sempre no modo de fazer nascer a justiça na alma de seus concidadãos e de banir a injustiça, de implantar nela a temperança $(\sigma \omega \varphi \rho o \sigma v ́ v \eta)$ e de afastar a intemperança $(\dot{\alpha} \kappa o \lambda \alpha \sigma i ́ \alpha){ }^{10}$.

Portanto, o uso apropriado, a saber, a utilização filosófica do logos, é uma espécie de preparação à vida ética, isto é, a existência humana enquanto expressão maior da virtude e da racionalidade que, por sua vez, está intrinsicamente relacionada à vida comum da pólis grega, local de expressão do logos e local de formação da própria philosophia.

Há assim um vínculo, desde sempre, entre discurso e filosofia, entre ética e política, entre o verdadeiro e o falso.

A filosofia de Platão expressa uma indignação com a política e os costumes vigentes de sua época. E o mesmo poder-se-ia dizer sobre os postulados filosóficos de Michel Foucault, ambos, portanto, encontram-se na utilização do logos filosófico que deve sempre exprimir a melhor intenção de racionalidade.

\section{Parresía, psicagogia e dialética}

Os três aspectos determinantes do logos, enquanto discurso, devem ser compostos de parrhesía, isto é, do dizer a verdade; da dialética (dialektikê), isto é, de razão filosófica enquanto pensamento, método e linguagem (dialógica); e de psicagogia, isto é, a condução das almas. Essas são as condições necessárias do uso apropriado do logos filosófico, sem nunca se eximir da tarefa paideística, que sempre objetiva a formação/configuração da virtude/excelência (areté) na alma.

Em sua obra Hermenêutica do sujeito (2006, p. 450-51), Foucault apresenta a seguinte definição do conceito de parrhesía: "O termo parrhesía está tão ligado à escolha, à decisão, à

\footnotetext{
${ }^{9}$ Foucault também apresenta estudos sobre o diálogo Górgias. Todavia, por questões de delimitação não se tratará deste diálogo. Para os interessados, a "aula de 09 de março de 1983" - segunda hora, trata do tema. Ver a edição supracitada.

${ }^{10}$ Conforme Trabattoni (2010, p. 295): “O saber filosófico e político [...] deve confiar pelo menos em parte da sua eficácia ao meio retórico da persuasão e da educação da alma.”
} 
Artigo: Contribuições de Michel Foucault ao estudo da filosofia antiga: o conceito de parrehsía aplicado ao Fedro de Platão

atitude de quem fala, que os latinos justamente traduziram parrhesía pela palavra libertas. O tudo-dizer da parrhesía tornou-se libertas: a liberdade de quem fala. "

A partir dessa interpretação foucaultiana do termo parrhesía, é possível reflexionar sobre o filosofar socrático e platônico, considerando estes como modos de excelência do parresiasta, porquanto eles jamais abandonaram o tudo-dizer para serem agradáveis a seus ouvintes ou adversários. Como corrobora o próprio Foucault (2010, p. 56): “Os parresiastas são os que, no limite, aceitam morrer por ter dito a verdade. Ou, mais exatamente, os parresiastas são os que empreendem dizer a verdade a um preço não determinado, que pode ir até sua própria morte."

Assim, pode-se deduzir que a parrhesía está vinculada à formação moral, do caráter (éthos) ético dos sujeitos ${ }^{11}$ que, por sua vez, identifica-se com os preceitos do conhecimento e do cuidado de si mesmo ${ }^{12}$. Portanto, como afirmado, aparece a finalidade de criar condições de educar a própria alma (psyché).

Nesse complexo processo compreende-se como primordial necessidade o vínculo entre o conceito de parrhesía e o conceito de refutação (elenktikós), porquanto não basta dizer a verdade ao ouvinte, é fundamental dizer a verdade a si mesmo. E não pode haver essa construção interna da verdade no desenrolar do próprio discurso sem o aceite da refutação, que é tanto a refutação dos argumentos do outro, como, e sempre, autorrefutação de si próprio.

A mesma exigência não é requisitada na simples utilização da tékhne retórica. Pois a retórica objetiva a persuasão mediante a utilização de técnicas argumentativas, e não fundamentadas no valor de verdade dos conceitos. Logo, os artifícios argumentativos dos sofistas e retóricos que objetivavam impedir a contradição e a refutação negam o uso dialético, parresiástico e psicagógico do logos.

Em consequência rompem não apenas com o uso apropriado do logos, como também participam da negação não filosófica de educar a alma dos outros e de si próprios na imprescindível educação moral. Encontra-se exata consonância com o diálogo Eutidemo (283 e), pois que o objetivo é a formação/configuração, neste caso particular, da psyché do jovem Clínias, para que este "se torne sábio e um homem de bem".

\footnotetext{
11 Os inimigos da parrhesía são a lisonja, inimigo moral do franco-falar, e a retórica, inimigo técnico. (FOUCAULT, 2006, p. 451).

${ }^{12}$ Consultar os diálogos platônicos Alcibíades Primeiro e Alcibíades Segundo, como também da Apologia de Sócrates. Foucault também faz destes diálogos objeto de seus estudos. Consultar também Hermenêutica do Sujeito.
} 
Esse ponto é de fundamental importância, porquanto posiciona a filosofia em franca oposição à educação proposta pelos sofistas, e a utilização da retórica enquanto procedimento técnico. Não basta saber utilizar-se de sofismas ou tornar-se mestre na arte refutatória, se em tal prática, não se considera a questão tanto do verdadeiro provável quanto da formação de uma conduta verdadeiramente ética. Nesse exato propósito observa-se no "diálogo tardio" Sofista (230 d):

[...] ela não alcançará [a alma], do que se lhe possa ingerir de ciência, benefício algum, até que se tenha submetido à refutação e que por esta refutação, causando-lhe vergonha de si mesma, se tenha desembaraçado das opiniões que cerram as vias do ensino e que tenha levado ao estado de manifesta pureza e a acreditar saber justamente o que ela sabe, mas nada além.

Por esta via torna-se evidente que o uso correto do logos não dispensa a utilização necessária do elenktikós socrático, largamente adotado nos Diálogos de Platão, constituindose como elementos cruciais da filosofia dialética que compõem a teia do logos argumentativo e formativo da philosophia.

Isso é crucial no sentido (novo), filosófico, dado a retórica, isto é, de seu uso ético e racional (dialético) ${ }^{13}$ no trato com o logos. Assim se coaduna outro elemento formador na utilização do logos filosófico e parresiástico, que se constitui no conceito de psicagogia (psykhagogía). Eis o que se encontra no diálogo Fedro (261 a-b):

Uma arte de conduzir as almas através das palavras, mediante o discurso, não só nos tribunais e locais públicos, mas também e qualquer espécie de assembleia privada? Uma arte que não varia consoante a grandeza ou a pequenez do assunto em vista? Uma arte cuja prática, isto é, cuja prática correta, é tão louvável para tratar de assuntos correntes como de assuntos nobres?

Observa-se que a psykhagogía é tékhne, que conduz as almas, mediante o uso apropriado do logos. O intuito da tékhne, como se apresenta, não se restringe aos locais de disputas públicas, por meio do discurso, mas também à vida privada, isto é, a vida primariamente formativa do indivíduo. É sobretudo na formação interior, subjetiva, que se deve alojar o desenvolvimento da virtude, da vida moral. É na relação interna do discurso

\footnotetext{
${ }^{13}$ No seguinte argumento do diálogo República $(539$ c-d), nota-se a responsabilidade necessária na utilização dialética do logos, o que se contrapõe ao uso da retórica procedimental dos sofistas: "Ao passo que quem é mais velho não quererá participar desta loucura, imitará o que quer discutir para indagar da verdade, de preferência àquele que se entretém a contradizer, pelo gosto de se divertir, ele mesmo será mais comedido e tomará a sua atividade mais honrada, em vez de mais desconsiderada." É evidente, portanto, que o fim da dialética se entrelaça a sua função parresiástica do desvelamento da verdade.
} 
Artigo: Contribuições de Michel Foucault ao estudo da filosofia antiga: o conceito de parrehsía aplicado ao Fedro de Platão

consigo próprio que a psicagogia filosófica tem de, primeiramente, cumprir a sua função paideística.

Por isso, conforme postula-se, não é possível se propor a conduzir os outros, sem, no entanto, de forma primária, saber conduzir a si próprio, o que torna imprescindível àquele que conduz, ao psicagogo, ao filósofo, conhecer e cuidar de si próprio. Assim, é imperioso que a psicagogia esteja diretamente vinculada a dialektikê. Como parece ser o caso da seguinte assertiva de Foucault (2010, p. 304):

Dialética e psicagogia são duas faces de um só e mesmo processo, de uma só e mesma arte, de uma só e mesma tékhne que é a tékhne do logos. Como o logos filosófico, a tékhne filosófica do logos é uma tékhne que possibilita ao mesmo tempo o conhecimento da verdade e a prática ou a ascese da alma sobre si mesma.

A partir desta interpretação, tem-se claro que o telos, ao qual nos referimos, como constituindo-se no objetivo da filosofia platônica, é o da educação da psyché. E para tornar possível a prática correta e eficiente da psicagogia, torna-se indispensável o concurso da dialética no mesmo processo na utilização apropriada do logos.

Para tanto, o conhecimento da alma ou dos diversos caracteres que cada alma possui, em si mesma, devem ser de conhecimento do filósofo conforme depreende-se do Fedro (271 d-e; 272 b). Do que se segue (273 e):

\begin{abstract}
Quem não tenha classificado os caracteres de seus futuros ouvintes; quem não for capaz de dividir as coisas existentes segundo os seus caracteres específicos, e de reunir objetos particulares numa só ideia geral; jamais chegará a ser um artista da oratória dentro das possibilidades humanas.
\end{abstract}

Evidencia-se que Platão não está se colocando em oposição, como já afirmado, à retórica em si mesma - intepretação esta, também sugerida por Foucault -, mas propondo um novo lugar à tékhne do $\operatorname{logos}{ }^{14}$. Por conseguinte, não deve a retórica ser considerada somente como um amontoado de procedimentos que objetivam não a verdade, mas sim, o convencimento; não o conhecimento e o cuidado para com a psyché, mas sim, o poder do mais forte; não a vida ética, ao menos como Platão a concebe, mas a vida prioritariamente hedonista.

\footnotetext{
14 McCoy (2010, p. 27) parece ter razão ao ajuizar que "a filosofia nos diálogos de Platão é sempre retórica, na medida em que o filósofo se orienta tanto ao amor pelas formas e ao amor pelas almas daqueles com quem se discute". O que claramente se ajusta na seguinte assertiva, Fedro (262 c): "Logo, meu amigo, quem não conhecer a verdade, mas só alimentar opiniões, transformará naturalmente a arte da retórica numa coisa ridícula, que nem sequer merece o nome de arte!"
} 
Parece ser plausível que, em certa medida, Platão concordaria com a seguinte sugestão de Aristóteles em sua obra Retórica (1355 b; 17-18), quando o estagirita conceitua o sofista: "Não é sua faculdade, mas seu propósito moral”. Portanto, não é o saber da retórica utilizado pelo sofista, mas a exclusão da eticidade do discurso.

É claro que se tem em jogo uma disputa, não somente pelo uso apropriado que se faz do logos, mas também, ou melhor, nesse jogo também faz parte, está nitidamente incluída a luta pelo lugar, o tópos de cada área dentro da pólis grega. Isso em um momento histórico em que o valor da palavra é altamente considerável tanto quanto a manifestação de racionalidade, mas ainda assim e, primordialmente, enquanto expressão de poder político, entendido como participação e convencimento do lugar que cada qual deve ocupar, e também contribuir, na comunidade política. Esse é um traço fundamental do plano teórico de Platão, esboçado claramente tanto no diálogo República, quanto nos diálogos tardios Político, Sofista e Leis.

Acertadamente, é possível concluir com Foucault o seguinte enunciado: "O filósofo por ser ao mesmo tempo dialético e psicagogo, o filósofo será verdadeiramente o parresiasta, e o único parresiasta, o que o retórico, o homem da retórica não é capaz de ser nem de fazer. "

Torna-se válido o argumento, mediante o qual Platão está propondo a fundamentação da própria filosofia ${ }^{15}$, área de um saber específico, devendo ser compreendida em sua utilidade indispensável tanto ao alcance formativo das individualidades, quanto ao seu uso público, isto é, a formação/configuração ideal da comunidade política (pólis) a partir da correta utilização do logos na paideia da alma.

O verdadeiro combate, necessário à afirmação da filosofia como saber útil e efetivamente proveitoso aos homens e a cidade, faz-se notar, mediante a severa crítica que Cálicles apresenta no diálogo Górgias à filosofia. Com certeza, Cálicles não se encontrava sozinho nessas convicções, que consideram supérfluo o saber e o discurso da filosofia.

Além de Cálicles considerar o estudo da filosofia útil somente aos jovens em formação, está a negar também qualquer valor da filosofia em relação à vida política e a formação do homem público, sendo mesmo "ridículo e tolo o homem que da filosofia assim

\footnotetext{
15 "Retórico, filósofo, sofista e poeta não são simplesmente termos que descrevem um conjunto de práticas, como médico ou pintor. Ao contrário, os termos ainda estão em desenvolvimento e são disputados com palavras na batalha sobre o que logos pode fazer. Os diálogos de Platão revelam sua sensibilidade em relação às dificuldades do uso apropriado do logos. " (McCoy, 2010, p. 27).
} 
Artigo: Contribuições de Michel Foucault ao estudo da filosofia antiga: o conceito de parrehsía aplicado ao Fedro de Platão

se ocupa". Em certo sentido, a filosofia de Platão é uma refutação quanto à utilização que o sofista Cálicles apresenta no uso indevido do $\log \mathrm{s}^{16}$.

É necessário, pois, romper decisivamente com a utilização sofística, e mesmo poética, da retórica como puro procedimento persuasivo. Somente pela orientação dialética conjugada à psicagogia pode haver abertura suficiente para a disposição do "falar-franco" da parrhesía, indispensável ao logos filosófico. Nesse sentido, compreende-se a seguinte crítica exposta no Fedro $(269$ b-c):

Esses homens, em virtude da sua incapacidade para discernir, limitaram-se aos conhecimentos básicos sobre a arte, julgando ter aprendido a própria retórica [assim como aquele que soubesse afinar uma corda, julgasse ser conhecedor da harmonia, cfr. 268 e]. Assim ensinam aos outros, estando convencidos de que formam oradores perfeitos, e pensam que os seus discípulos devem procurar falar sobre qualquer tema, sempre de modo persuasivo.

Logo, como propõe Foucault (2010, p. 305): “A filosofia é étymos tékhne (a técnica autêntica) do discurso verdadeiro."

\section{CONCLUSÃO}

Se o logos filosófico, enquanto expressão necessária de parrhesía, de psicagogia e de dialética, interfere diretamente na formação educacional dos indivíduos e da comunidade política, o seu uso meramente procedimental, retórico, demonstra, igualmente, o pernicioso

\footnotetext{
${ }^{16}$ Eis o argumento de Cálicles (484 c - 485 e): "Essa é a verdade, que tu mesmo (“Sócrates") reconhecerias se deixasses de lado a filosofia e te dedicasses a ocupações mais importantes. A filosofia, "Sócrates", é, de fato, muito atraente para quem a estuda com moderação na mocidade, porém acaba por arruinar quem a ela se dedica mais tempo do que fora razoável. Por bem-dotada que seja uma pessoa, se prosseguir filosofando até uma idade avançada, forçosamente ficará ignorando tudo o que importa conhecer o cidadão prestante e bem-nascido que ambicionar distinguir-se. De fato, não somente desconhecerá as leis da cidade, como a linguagem que será preciso usar no trato público ou particular, bem como carecerá de experiência com relação aos prazeres e a às paixões e ao caráter geral dos homens. Logo que procuram ocupar-se com seus próprios negócios ou com a política, tornam-se ridículos, como ridículos, a meu ver, também se tornam os políticos que se dispõem a tomar parte em vossas reuniões e vossas disputas. [...] É belo o estudo da filosofia até onde for auxiliar da educação dos jovens. Mas prosseguir neste estudo até idade avançada, é coisa ridícula, Sócrates, reagindo eu à vista de quem assim procede como diante de quem se põe a balbuciar e a brincar como criança. Quando vejo uma criança na idade de falar dessa maneira, balbuciando e brincando, alegro-me e acho encantador o espetáculo, digno de uma criatura livre e muito de acordo com aquela fase da existência; porém se ouço uma criaturinha articular com correção as palavras, deem-se os ouvidos e acho por demais forçado essa maneira de falar, que se me afigura linguagem de escravos. Falar um adulto, pelo contrário, ou brincar como criança, é procedimento ridículo, indigno de homens e merecedor de açoites. É precisamente isso que se dá comigo em relação aos que se dedicam à filosofia. [...] quem assim procede, por mais bem-dotado que seja, deixa de ser homem; foge do coração da cidade e das assembleias, onde, exclusivamente, no dizer do poeta, os homens se distinguem, para meter-se num canto o resto da vida, a cochichar com três ou quatro moços, sem jamais proferir um discurso livre, grande ou generoso."
} 
alcance quando de sua má utilização. Isto é, o logos, quando somente manifestação de poder discursivo para a persuasão e conquistas de benefícios circunstanciais, em desvínculo da verdade e de legítima formação moral e política, atrela-se aos perigos da má paideía.

Em consequência, tem-se indivíduos sujeitados ao pior tipo de ignorância, que conforme a tradição socrático-platônica corresponde: a pensar saber o que não sabe. Esse erro de crença, que não passa de simples falsidade opiniática, quando somado à possibilidade de governo, é causa dos piores males tanto à pólis quanto às individualidades que a compõem.

A filósofa Julia Annas (1999, p. 120) contribui com a argumentação apresentada, quando ajuíza que "mediante o que dizem historiadores modernos da filosofia, Sócrates seria um exemplo de vida filosófica, enquanto uma psicologia moral seria corretamente atribuída a Platão".

Sócrates fora exemplarmente filósofo. A sua existência foi a expressão plena do logos filosófico, em sua dimensão pensante e discursiva. Ainda mais, fez de sua práxis a direta manifestação de racionalidade. O intelectualismo socrático-platônico manifesta não somente o imperativo da razão, mas a primordial necessidade de vincular à racionalidade a eticidade do discurso e da ação.

Portanto, não basta bem pensar e utilizar com habilidade o raciocínio e o discurso, mas é imprescindível fazer do pensamento e da palavra ferramentas para a ascese da psyché. É sobretudo nesse sentido que a ética jamais pode ser separada do logos. O uso apropriado do logos é propulsão de aperfeiçoamento moral, bem como da formação de uma comunidade política, fundamentada em princípios de Justiça e Bem.

O uso procedimental da palavra sem aqueles princípios, não valem, senão a título de exaltação da própria personalidade. Assim, o lugar apropriado da retórica é de auxiliar aquela que verdadeiramente corresponde ao logos enquanto razão e enquanto discurso, isto é, a filosofia.

De acordo com Foucault, a filosofia no longo espaço que compreende a Antiguidade é expressão característica e formadora a partir de dois princípios fundamentais: o conhecimento e o cuidado de si mesmo. É nesse ponto que o logos filosófico assume as dimensões formadoras, e portanto política e ética na construção de um novo ethos na alma humana. São novos parâmetros para a racionalidade e de uma efetiva vida ética ao mundo antigo.

Nesses termos, o rompimento com o que se denominou de retórica procedimental torna-se inevitável mediante o logos filosófico. Porém, como bem demonstrado por Foucault, 
a questão não era menos se o logos seria a expressão de oralidade ou de escrita, mas sim, se as intenções do discurso eram moralmente válidos.

Assim, somente pode lograr êxito semelhante proposta formadora de um novo ethos grego a partir da consideração das três prévias dimensões apresentadas ao logos filosófico que, ao que parece, Foucault compreendeu em profundidade.

Em suma, a realização do logos apresentado pela philosophia de Platão somente se efetiva na medida em que se fala francamente a verdade (parrhesía), tornado a psyché o melhor possível em sua correta condução (psykhagogía) e, assim, dialeticamente, constróemse novos paradigmas de racionalidade e conduta, mediante a elucidação e a apropriação correta e ética do logos.

O espaço e o local (tópos), portanto, da formação moral e epistêmica das individualidades, no uso apropriado do logos, trazem consigo o valor próprio da filosofia, porquanto deve ser através do saber filosófico que se tem as condições necessárias para a formação do discurso verdadeiro a ser realizado no interior da própria psyché que fala a verdade para si mesma, conduzindo-se, de maneira que esta verdade possa ser compartilhada na dialogia do logos platônico, na profunda configuração de novas subjetividades não sujeitadas às máscaras da demagogia e ou da lisonja.

\section{REFERÊNCIAS}

ANNAS, J. Platonic Ethics: Old and New. U.S.A: Cornell University Press, 1999.

FOUCAULT, M. O governo de si e dos outros. Curso no Collège de France (1982-1983); Edição estabelecida por Fréderic Gros sob a direção de François Ewald e Alessandro Fontana. Tradução Eduardo Brandão. Martins Fontes: São Paulo, 2010.

FOUCAULT, M. A hermenêutica do sujeito. Curso dado no Collège de France (1981-1982). Tradução Márcio Alves da Fonseca e Salma Tannus Muchail. São Paulo: Martins Fontes, 2006.

GOBRY, I. Vocabulário grego da filosofia. Tradução Ivone c. Benedetti. ver., Jacira de Freitas. Caracteres gregos e transliteração do grego Zelia de Almeida Cardoso. São Paulo: Martins fontes, 2007.

HADOT, P. Elogio da Filosofia Antiga. Aula inaugural da cadeira de história do pensamento helenístico e romano, pronunciada no Collège de France, na sexta-feira, 18 de fevereiro de 1983. Tradução Flávio Fontenelle Loque [et al.] São Paulo: Edições Loyola, 2012. (Leituras Filosóficas). 
McCOY, M. Platão e a retórica de filósofos e sofistas. Tradução Lívia Oushiro. São Paulo: Madras, 2010.

PLATÃO. Fedro. Tradução Pinharanda Gomes. Lisboa: Guimarães Editores, 1989.

PLATÃO. Carta VII. Texto estabelecido e anotado por John Burnet. Introdução Terence H. Irwin. Tradução José Trindade Santos e Juvino Maia Jr. Rio de Janeiro: Ed. PUC-Rio; São Paulo: Loyola, 2008.

PLATÃO. Diálogos: Sofista e Político. Tradução Jorge Paleikat e João Cruz Costa. São Paulo: Abril Cultural, 1972.

PLATÃO. Diálogos: Apologia de Sócrates, Críton, Laques, Cármides, Lísis, Eutífron, Protágoras, Górgias. Tradução Carlos Alberto Nunes. São Paulo: Edições Melhoramentos, 1970.

SZLEZÁK, T. A. Ler Platão. Tradução Milton Camargo Mota. São Paulo: Edições Loyola, 2005.

TRABATTONI, F. Platão. Tradução Rineu Quinalia. São Paulo: Annablume, 2010. (Coleção Archai: as origens do pensamento ocidental, 2). 